\title{
PENERAPAN PASAL 3 PERATURAN DAERAH KABUPATEN INDRAGIRI HILIR NOMOR 25 TAHUN 2010 TENTANG RETRIBUSI IZIN USAHA PERIKANAN DI KECAMATAN TEMBILAHAN
}

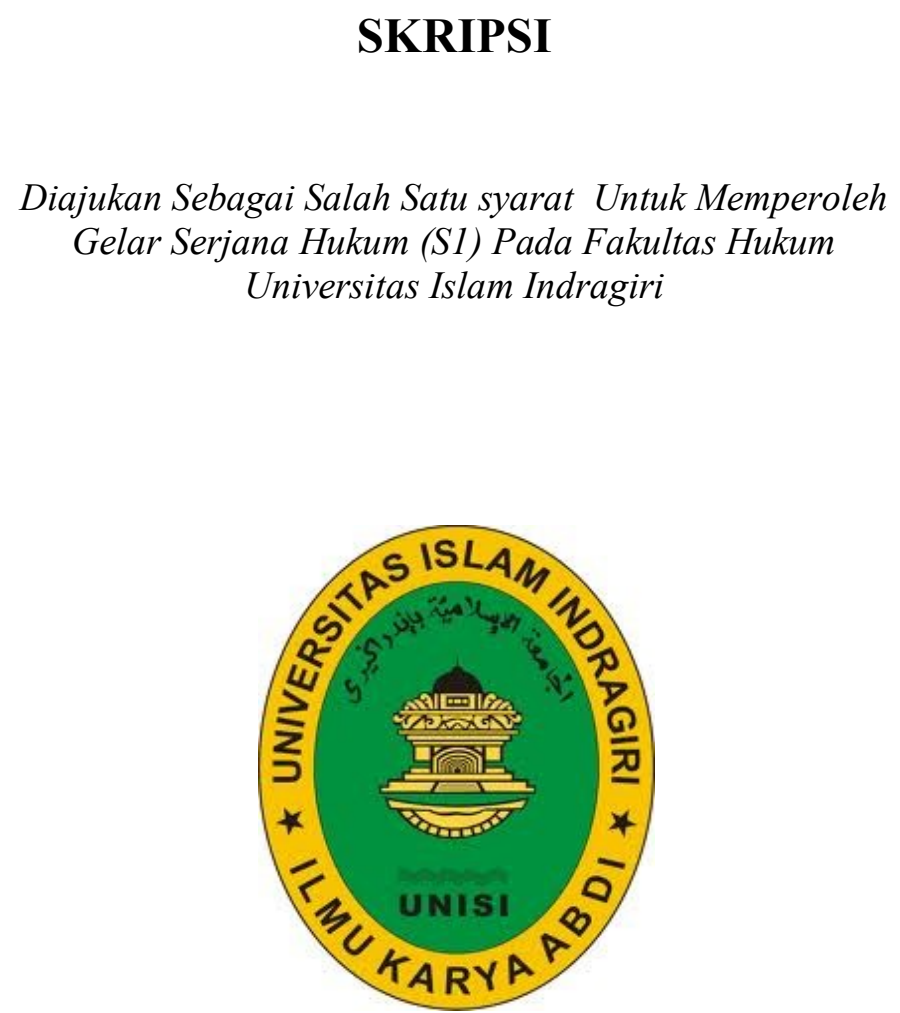

OLEH :

AHMAD ZAIRIN INDRA

NIM :301121010004

FAKULTAS HUKUM

UNIVERSITAS ISLAM INDRAGIRI

TEMBILAHAN

2017 


\section{BAB I}

\section{PENDAHULUAN}

\section{A. Latar Belakang Masalah}

Dalam Undang-Undang Dasar 1945 Pasal (1) Negara indonesia adalah negara kesatuan yang berbentuk republik. ${ }^{1}$ Indonesia pada dasarnya penyelenggaraan urusan pemerintahan berada pada kekuasaan pemerintahan pusat dan pemerintahan daerah hanyalah melaksanakan urusan-urusan pemerintahan yang diberikan oleh pemerintah pusat melalui desentralisasi, dekonsentrasi maupun tugas pembantuan.

Penerapan desentralisasi dan dekonsentrasi pada negara kesatuan adalah merupakan perwujudan dari distribution of power antara pemerintah pusat dan pemerintah daerah. Sebagai konsekuensinya terjadi penyerahan dan/atau pelimpahan urusan pemerintah pusat. ${ }^{2}$

Berlakunya Undang-Undang Nomor 32 Tahun 2004 tentang Pemerintah Daerah, maka terjadi perubahan terhadap sistem pemerintahan nasional. Perubahan sistem pemerintahan nasional tersebut terlihat pada asas pemerintahan. Dengan pemberlakuan undang-undang tersebut maka terjadi suatu perubahan asas yang semula bersifat sentralisasi menjadi asas yang bersifat desentralisasi.

Penyelenggaraan otonomi daerah dilaksanakan dengan memberikan kewenangan yang luas, nyata dan bertanggung jawab dalam rangka peningkatan pelayanan dan kesejahteraan masyarakat. Pengembangan kehidupan demokrasi,

\footnotetext{
${ }^{1}$ Undang-Undang Dasar 1945 hlm. 84

${ }^{2}$ Moh.Kusnardi dan Bintan R.Saragih, Ilmu Negara, PT.Gaya Media Pratama, Jakarta, 1993,
} 
keadilan, dan pemerataan serta pemeliharaan hubungan yang serasi antara pemerintah pusat dan pemerintah daerah.

Otonomi Daerah telah membawa perubahan yang cukup signifikan dalam tata pemerintahan di Indonesia. Otonomi daerah merupakan esensi pemerintahaan desentralisasi. Otonomi berasal dari bahasa Yunani, yakni autos yang berarti sendiri dan nomos yang berarti undang-undang. Menurut Ni'matul Huda otonomi luas bisa bertolak dari prinsip "Semua urusan pemerintahan pada dasarnya menjadi urusan rumah tangga daerah, kecuali yang ditentukan sebagai urusan pusat. Dalam negara moderen, lebih-lebih apabila dikaitkan dengan paham negara kesejahteraan, urusan pemerintahan tidak dapat dikenali jumlahnya". 3

Fungsi utama pemerintah daerah menurut Undang-Undang Nomor 32 Tahun 2004 Pasal 2 (3) yaitu Pemerintah daerah menjalankan otonomi seluasluasnya kecuali urusan pemerintahan yang menjadi urusan pemerintah,dengan tujuan meningkatkan kesejahteraan masyarakat, kelayanan umum, dan daya saing daerah. Dan dalam Pasal 2 (b) yaitu hubungan keuangan, pelayanan umum, pemerataan sumber daya alam, dan sumber daya lainnya secara adil dan selaras. ${ }^{4}$

Disamping itu, Undang-Undang Nomor 32 Tahun 2004 tentang Pemerintahan Daerah telah membagi urusan pemerintahan antara pemerintah pusat dan pemerintah daerah.

Hak-hak suatu daerah adalah mengatur dan mengurusi sendiri urusan pemerintahannya, memilih pemimpin daerah, mengelola pegawai daerah,

\footnotetext{
${ }^{3}$ Ni'matul Huda, Problematika Pembatalan Peraturan Daerah, FH UII Press, Yogyakarta, 2010, hlm. 45

${ }^{4}$ Undang-undang Nomor 32 tahun 2004 Tentang Otonomi Daerah
} 
mendapatkan sumber-sumber pendapatan lain yang sah, mendapatkan hak lainnya yang diatur dalam peraturan perundang-undangan.

Dalam rangka efektifitas pelaksanaan pembangunan di segala bidang, demi tercapainya keselarasan dan keseimbangan seluruh kegiatan pembangunan, bagi seluruh rakyat. Oleh karena itu tidak semua urusan pemerintahan dilaksanakan oleh pemerintah pusat, akan tetapi daerah diberikan kewenangan untuk mengurus rumah tangganya sendiri. Maka sistem pemerintahan Negara Indonesia yang merupakan Negara Kesatuan berbentuk Republik, dibentuk pemerintahan daerah sesuai Pasal 18 Undang-undang Dasar Negara Republik Indonesia tahun $1945 .{ }^{5}$

Perkembangan Pemerintahan Daerah di Indonesia sudah dimulai sejak Pemerintah Kolonial Belanda pada Tahun 1903 dengan mengeluarkan Desentralisatie Wet merupakan dasar hukum pertama berkaitan desentralisasi di Indonesia, yang memberik kekuasaan dalam pelaksanaan implementatif kebijakan desentralisasi untuk dan di Hindia Belanda. Desentralisatie Wet 1903 merupakan hasil amandemen persial dari RR 1854 dengan cara memberikan tambahan tiga pasal baru diantara Pasal 68 dan Pasal 69 RR 1854. Pada dasarnya perundangundangan desentralisasi dimaksudkan untuk membuka kemungkinan terwujudnya pemerintahan lokal di daerah-daerah tertentu atau bagian-bagian dari satuan-satuan daerah tertentu, yang dapat melaksanakan urusan pemerintahannya sendiri. ${ }^{6}$

Dalam sistem ketatanegaraan di Indonesia prinsip pembagian kewenangan berdasarkan atas asas Dekonsentrasi dan Desentralisasi dalam kerangka Kesatuan Republik Indonesia, Daerah yang dibentuk dengan asas Desentralisasi berwenang

${ }^{5}$ Pasal 18 Undang-undang Dasar 1945

${ }^{6}$ Soetandyo Wignjosoebroto, Desentralisasi dalam Tata Pemerintahan Kolonial HindiaBelanda (Kebijakan dan Upaya Sepanjang Babak Akhir Kekuasaan Kolonial di Indonesia 1900 1940), Bayumedia Publishing, Malang, 2005, hlm. 16 
untuk melaksanakan kebijakan atas prakarsa sendiri berdasarkan aspirasi masyarakat.

Prinsip penyelenggaraan Pemerintah Desentralisasi inilah yang melatarbelakangi lahirnya otonomi daerah yang sesuai dengan Undang-Undang Nomor 22 Tahun 1999 yang kini diperbarui dengan Undang-Undang Nomor 32 Tahun 2004 tentang Pemerintah Daerah.

Kewajiban suatu daerah adalah menyediakan sarana sosial dan sarana umum yang layak yang bersangkutan, melestarikan lingkungan hidup, membentuk dan menerapkan, mengembangkan sistem jaminan sosial, menyusun perencanaan dan teta ruang pada daerah berbagai peraturan perundang-undangan yang sesuai dengan kewenangannya.

Dinas daerah dipimpin oleh kepala dinas yang diangkat dan diberhentikan kepala daerah, yang memenuhi syarat atas usul sekretaris daerah. Kepala dinas dalam melaksanakan tugasnya bertanggung jawab kepada kepala daerah melalui sekretaris daerah. Misalnya, dinas perikanan yang bertugas mengurus dan mengelola masalah perikanan.

Lembaga ini merupakan unsur pendukung tugas kepala daerah. Tugasnya berperan dalam penyusunan dan pelaksanaan kebijakan daerah yang bersifat khusus. Lembaga teknis daerah berbentuk badan, kantor, atau rumah sakit umum daerah. Lembaga-lembaga tersebut dipimpin kepala badan, kepala kantor, dan direktur rumah sakit umum. Mereka diangkat oleh kepala daerah yang memenuhi syarat atas usul sekretaris daerah.

Dalam Undang-Undang Nomor 33 Tahun 2004 Pasal 1 Ayat (3) menyebutkan bahwa perimbangan keuangan antara pemerintah dan pemerintahan 
daerah adalah suatu sistem pembagian keuangan yang adil, proporsional, demokratis, transparan, dan efisien dalam rangka pendanaan penyelenggaraan desentralisasi dengan mempertimbangkan potensi, kondisi, dan kebutuhan daerah serta besaran pendanaan penyelenggaraan desentralisasi dan tugas pembantuan.

Perimbangan keuangan antara pemerintan dan pemerintahan daerah merupakan subsistem keuangan negara sebagai konsekuensi pembagian tugas antara pemerintah dan pemerintahan daerah pemberian sumber keuangan kepada pemerintahan daerah dalam rangka pelaksanaan desentralisasi didasarkan atas penyerahan tugas oleh pemerintah kepada pemerintah daerah dengan memperhatikan stabilitas dan keseimbangan fiskal dan tentunya perimbangan keuangan antara pemerintahan dan pemerintahan daerah merupakan suatu sistem yang menyeluruh.

Penyelenggaraan urusan pemerintahan daerah dalam pelaksaan desentralisasi di danai oleh APBD sedangkan pemerintah yang dilaksanakn oleh gubernur pelaksanaan dekonsentrasi dan tugas pembantuan di danai oleh APBN.

Dalam sumber penerimaan daerah, pendapatan daerah bersumber dari ${ }^{7}$

1. DAK (Dana Alokasi Khusus) yaitu dana yang bersumber dari pendapatan APBN yang dialokasikan kepada daerah tentunya dengan tujuan untuk membantu mendanai kegiatan khusus yang merupakan urusan daerah dan sesuai dengan prioritas nasional.

2. DAU (Dana Alokasi Umum) yaitu dana yang bersumber dari pendapatan APBN yang dialokasikan dengan tujuan pemerataan kemampuan keuangan antar daerah untuk mendanai kebutuhan daerah dalam rangka pelaksanaan desentralisasi.

${ }^{7}$ Undang-Undang Nomor 33 Tahun 2004 Tentang Perimbangan Keuangan 
3. PAD (Pendapatan Asli Daerah) yaitu pendapatan yang diperoleh daerah yang dipungut berdasarkan perda sesuai dengan praturan perundang-undangan.

Salah satunya sebagai produk hukum daerah yaitu keluarnya Peraturan Daerah kabupaten Indragiri Hilir Nomor 25 Tahun 2010 Tentang Retribusi Izin Usaha Perikanan yang menyebutkan sebagai berikut yaitu dalam Pasal 3 Perda Inhil Nomor 25 Tahun 2010;

1. Setiap orang atau badan yang melakukan usaha perikanan di bidang penangkapan, pengakutan, pengolahan, dan pemasaran ikan di daerah wajib memiliki izin.

2. Kewajiban memiliki izin sebagaimana yang di maksud pada ayat (1) tidak berlaku bagi nelayan kecil dan atau pembudidaya ikan kecil.

Guna menunjang pembangunan pemerintah diperlukan peran segala pihak termasuk para nelayan dalam memberikan retribusi daerah. Sebagai pendukung/menimbang mengenai penjelasan Pasal diatas, dalam Pasal 1 Peraturan Daerah Nomor 25 Tahun 2010 menjelaskan bahwa: ${ }^{9}$

1. Perikanan adalah semua kegiatan yang berhubungan dengan pengelolaan dan pemanfaatan sumber daya ikan dan lingkungannya sampai dengan pemasaran yang dilaksanakan dalam suatu sistem bisnis perikanan.

2. Usaha perikanan adalah semua usaha perorangan atau badan hukum untuk menangkap dan atau membudidayakan ikan untuk tujuan komersial.

3. Penangkapan ikan adalah kegiatan untuk memperoleh ikan di perairan, termasuk kegiatan yang menggunakan kapal untuk memuat, mengangkut, menyimpan, mendinginkan, menangani, mengolah, dan/atau mengawetkannya.

\footnotetext{
${ }^{8}$ Undang-Undang Nomor 25 Tahun 2010 Tentang Retribusi Izin Usaha Perikanan

${ }^{9}$ Undang-Undang Nomor 25 Tahun 2010 Tentang Retribusi Izin Usaha Perikanan
} 
Besarnya tarif retribusi izin usaha perikanan yang harus dibayarkan pada

Bab VIII Pasal 14 sebagai berikut:

Tabel I.1 Tarif Retribusi Izin Usaha Perikanan

\begin{tabular}{|c|c|c|c|c|}
\hline No & Jenis izin & Satuan & $\begin{array}{c}\text { Tarif } \\
\text { Retribusi }\end{array}$ & Ket \\
\hline \multirow[t]{32}{*}{ I } & Usaha Perikanan & & & \\
\hline & 1.Lampara Dasar & Perunit & 500.000 & \\
\hline & 2.Lampara dasar mini & Perunit & 300.000 & \\
\hline & 3.Gombang & Perunit & 250.000 & \\
\hline & 4.Gil Net Pantai & Perunit & 150.000 & \\
\hline & 5.Gill net laut & Perunit & 250.000 & \\
\hline & 6.Sondong & Perunit & 200.000 & \\
\hline & 7.Rawai & Perunit & 200.000 & \\
\hline & 8.Togok laut & Perunit & 200.000 & \\
\hline & 9.Togok pantai & Perunit & 100.000 & \\
\hline & 10.Belat pantai & Perunit & 150.000 & \\
\hline & 11.Jermal & Perunit & 250.000 & \\
\hline & 12.Kelong & & 200.000 & \\
\hline & 13.Usaha pengumpul ikan & & & \\
\hline & a.Udang beku & $\mathrm{s} / \mathrm{d} 2$ ton & 500.000 & \\
\hline & & $>2$ ton $\mathrm{s} / \mathrm{d} 5$ ton & 1.000 .000 & \\
\hline & & $>5$ ton & 3.000 .000 & \\
\hline & b.Udang/ikan segar & s/d 2 ton & 500.000 & \\
\hline & & $>2$ ton $\mathrm{s} / \mathrm{d} 5$ ton & 1.000 .000 & \\
\hline & & $>5$ ton & 1.500 .000 & \\
\hline & c.Udang/ikan/kepiting & $\mathrm{s} / \mathrm{d} 2$ ton & 500.000 & \\
\hline & hidup & $>2$ ton $\mathrm{s} / \mathrm{d} 5$ ton & 1.500 .000 & \\
\hline & & $>5$ ton & 3.000 .000 & \\
\hline & d.Ebi/udang kering & $\mathrm{s} / \mathrm{d} 2$ ton & 500.000 & \\
\hline & & $>2$ ton $\mathrm{s} / \mathrm{d} 5$ ton & 1.500 .000 & \\
\hline & & $>5$ ton & 2.000 .000 & \\
\hline & e.Ikan asin/terasi & $\mathrm{s} / \mathrm{d} 2$ ton & 200.000 & \\
\hline & & $>2$ ton $\mathrm{s} / \mathrm{d} 5$ ton & 500.000 & \\
\hline & & $>5$ ton & 1.000 .000 & \\
\hline & 14.Pengangkutan & $\mathrm{s} / \mathrm{d} 2$ ton & 500.000 & \\
\hline & ikan/udang/ebi/terasi & $>2$ ton $\mathrm{s} / \mathrm{d} 5$ ton & 1.000 .000 & \\
\hline & & $>5$ ton & 2.000 .000 & \\
\hline
\end{tabular}

Sumber: Undang-Undang Nomor 25 Tahun 2010 Tentang Retribusi Izin Usaha Perikanan

Berdasarkan hal tersebut diatas dapat disimpulkan yaitu terjadi pelimpahan urusan pemerintahan pusat kepada kepala daerah yaitu dalam Undang-Undang 
Nomor 23 Tahun 2014 tentang Pemerintahan Daerah Pasal 1 Ayat 3 disebutkan bahwa, Pemerintah Daerah adalah kepala daerah sebagai unsur penyelenggara Pemerintahan Daerah yang memimpin pelaksanaan urusan pemerintahan yang menjadi kewenangan daerah otonom. Salah satu contoh adalah pelimpahan wewenang kepemerintah daerah di kota Tembilahan yang telah terbentuknya/dikeluarkannya Peraturan Daerah Nomor 25 Tahun 2010 Tentang Retribusi Izin Usaha Perikanan oleh DPRD dan Bupati pada tanggal 30 Desember 2010, diharapkan dapat mengisi kas negara/kas daerah otonom guna memenuhi kehidupan rutinnya dan dapat memakmurkan masyarakat melalui jasa yang diberikan secara langsung setelah dikeluarkannya Perda Inhil ini.

Berdasarkan penjelasan di atas dan obervasi awal yang dilakukan oleh penulis, penulis mengambil judul PENERAPAN PASAL 3 PERATURAN DAERAH KABUPATEN INDRAGIRI HILIR NOMOR 25 TAHUN 2010 TENTANG RETRIBUSI IZIN USAHA PERIKANAN DIKECAMATAN TEMBILAHAN

\section{B. Rumusan Masalah}

Berdasarkan latar belakang tersebut diatas, maka penulis merumuskannya dalam permasalahan sebagai berikut:

1. Bagaimana penerapan Pasal 3 Peraturan Daerah Nomor 25 Tahun 2010 Tentang Retribusi izin usaha perikanan?

2. Apakah yang menjadi faktor penghambat dalam penerapan Pasal 3 Peraturan Daerah Nomor 25 Tahun 2010 Tentang Retribusi izin usaha perikanan? 


\section{Tujuan Penelitian}

Lazimnya setiap penulisan karya ilmiah senantiasa mempunyai tujuan tertentu yang ingin dicapai. Demikian halnya dengan penulisan ini, mempunyai tujuan untuk mengetahui dan mengkaji serta menganalisis:

1. Untuk mengetahui penerapan Pasal 3 Peraturan Daerah Nomor 25 Tahun 2010 Tentang Retribusi izin usaha perikanan.

2. Untuk mengetahui faktor apa yang menjadi penghambat dalam penerapan Pasal 3 Peraturan Daerah Nomor 25 Tahun 2010 Tentang Retribusi izin usaha perikanan.

\section{Manfaat Penelitian}

Adapun kegunaan dari penelitian ini adalah sebagai berikut:

\section{Aspek Teoritis}

a) Sebagai sumbangan pemikiran bagi pengembangan ilmu pengetahuan mengenai Retribusi Izin Usaha Perikanan pada umumnya dan Hukum Tata Negara dalam memahami dan mempelajari masalah urusan Peraturan Daerah pada khususnya.

b) Penelitian ini akan memberi sumbangan pengetahuan ilmu atau dapat merupakan sebagai bahan bacaan (perpustakaan) bagi mahasiswa khususnya fakultas hukum universitas indragiri.

\section{Aspek Praktis}

Penelitian ini diharapkan dapat mengoptimalisasikan penerapan Peraturan Daerah Nomor 25 Tahun 2010 Tentang Retribusi izin usaha perikanan di kecamatan Tembilahan. 


\section{E. Kerangka Teori}

\section{Negara Kesejahteraan}

Negara kesejahteraan adalah konsep pemerintahan ketika negara mengambil peran penting dalam perlindungan dan pengutamaan kesejahteraan ekonomi dan sosial warga negaranya. Konsep ini didasarkan pada prinsip kesetaraan kesempatan, distribusi kekayaan yang setara, dan tanggung jawab masyarakat kepada orang-orang yang tidak mampu memenuhi persyaratan minimal untuk menjalani kehidupan yang layak. Istilah ini secara umum bisa mencakup berbagai macam organisasi ekonomi dan sosial.

Unsur negara dikenal 3 hal yaitu;

1. Wilayah

2. Rakyat

\section{Pemerintahan}

Dalam pemegang kekuasaan menurut Miriam Budiardjo kekuasaan di artikan sebagai kemampuan seeorang atau kelompok manusia untuk mempengaruhi tingkah laku seseorang atau orang lain demikian rupa sehingga tingkah laku itu menjadi sesuai dengan keinginan dan tujuan dari orang yang mempunyai kekuasaan itu. ${ }^{10}$

Konstitusi yang diartikan sebagai hukum dasar baik yang tertulis maupun tidak tertulis. Hukum dasar yang tertulis disebut sebagai undang-undang dasar sedangkan hukum yang tidak tertulis disebut konvensi yaitu kekuasaan ketatanegaraan/aturan warga negara. ${ }^{11}$ hlm. 65

${ }^{10}$ Miriam Budiardjo, Dasar-Dasar Ilmu Politik, PT. Gramedia Pustaka Utama, Jakarta, 2008,

\footnotetext{
${ }^{11}$ Soetandyo Wignjosoebroto, Op.Cit., hlm. 43
} 
Aturan yang dasar yang timbul dan terpelihara dalam praktek penyelenggaraan negara. Konstitusi sebagai aliran kodifikasi yaitu dengan menghendaki sebagai hukum tertulis dengan maksud untuk;

1. Mencapai kesatuan hukum

2. Kesederhanaan hukum.

3. Kepasstian hukum.

Suatu peraturan hukum yang tertulis (UUD) salah satu bagian dari konstitusi. Dalam setiap konstitusi yang modern ada tercantum bahwa tujuan negara adalah untuk memelihara dan mengembangkan kesejahteraan dan keselamatan warga negara. ${ }^{12}$

Dalam konstitusi indonesia dapat dilihat pada pembukaan dan batang tubuh UUD 1945. Dalam pembukaan disebutkan dalam alenia ke4 yaitu;

Kemudian dari itu untuk membentuk suatu pemerintahan negara indonesia yang melindungi segenap bangsa indonesia danseluruh tumpah darah indonesia dan memajukan kesejahteran umum,mencerdaskan kehidupan bangsa dan ikut melaksanakan ketertiban dunia yang berdasarkan kemerdekaan dan perdamaian abadi dan keadilan sosial maka dissusunlah kemerdekaan bangsa negara indonesia itu didalam suatu undang-undang dasar negara indonesia yang berkedaulatan rakyat yang berdsarkan kepada ketuhanan yanh maha esa,kemanusiaan yang adil dan beradab,persatuan indonesia,dan kerakyatan yang dipimpin oleh kebijaksanaan dalam permusyaaratan perwakilan serta dengan mewujudkan keadian sosial bagi seluruh rakyat indonesai.

12 Moh.Kusnardi dan Bintan R.Saragih, Ilmu Negara. PT.Gaya Media Pratama, Jakarta, 1993, 
Menurut Moh Yamin memajukan kesejahteraan umum,mencerdaskan kehidupan bangsa serta untuk mencapai kebahagia dalam negri adalah tujuan nasional sedangkan tujuan internasional adalah melaksanakan ketertiban dunia yang berdarkan kemerdekaan perdamaian abadi dan keadilan sosial. ${ }^{13}$

Sistem pemerintahan indonesia menganut sistem demokratis,dala sistem ini badan legislatif tunduk pada kontrol langsung rakyat, kontrol langsung rakyat ini dapat langsung dilakukan dengan 2 cara;

1. Inisiatif rakyat yaitu hakrakyat untuk mengajukan/mengusulkan suatu rancangan undang-undang kepada legislatif.

2. Referendum yaitu permintaan/persetujuan dan atau pendapat rakyat apakah setuju atau tidak terhadap kebijaksaan yang telah, sedang/akan dilaksanakan oleh badan legislatif dan eksekutif.

Dalam Pasal 2 Undang-Undang Dasar Nomor 39 tahun 1999 tentang Hak Asasi Manusia negara indonesia mengakui dan menjunjung tinggi hak asasi manusia dan kebebasan dasar manusia sebagai hak kodrati tidak terpisahkan dari manusia harus dilindungi, dihormati, dan ditegakkan demi peningkatan martabat kemanusiaan, kesejahteraan, kebahagiaan, dan kecerdasan serta keadilan.

\section{Teori Kewenangan}

Pasal 1 Angka 7 Undang-Undang Nomor 10 Tahun 2004 Tentang Pembentukan Peraturan Perundang-Undangan, mendefinisikan bahwa Peraturan Daerah adalah Peraturan Perundang-undangan yang dibentuk oleh dewan perwakilan rakyat daerah dengan persetujuan bersama kepala daerah. ${ }^{14}$

\footnotetext{
${ }^{13}$ Ibid, hlm, 155

14 Undang-Undang Nomor 10 Tahun 2004 Tentang pembentukan peraturan perundang undangan
} 
Peraturan Daerah Kabupaten/Kota adalah peraturan yang dibentuk oleh Bupati atau Walikota/Kepala Daerah Kabupaten/Kota bersama-sama dengan Dewan Perwakilan Daerah Kabupaten/Kota, dalam melaksanakan otonomi daerah yang diberikan kepada Pemerintah Daerah Kabupaten/Kota, yaitu Bupati atau Walikota/Kepala Daerah Kabupaten/Kota dan Dewan Perwakilan Rakyat Daerah Kabupaten/Kota. ${ }^{15}$

Dalam Pasal 14 menyebutkan bahwa urusan wajib yang menjadi kewenangan pemerintahan daerah kabupaten/kota merupakan urusan berskala kabupaten/kota yang meliputi; ${ }^{16}$

1. Perencanaan dan pengendalian pembangunan

2. Perencanaan, pemanfaatan, dan pengawasan tata ruang

3. Penyelenggaraan ketertiban umum dan ketentraman masyarakat

4. Penyediaan sarana dan prasarana umum

5. Penanganan dibidang ksehatan

6. Penyelenggaraan pendidikan

7. Penanggulangan masalah sosial

8. Pelayanan dibidang ketenagakerjaan

9. Fasilitas pengembangan koperasi, usaha kecil dan menengah

10. Pengendalian lingkungan hidup.

Urusan pemerintahan kabupaten/kota yang bersifat pilihan meliputi urusan pemerintahan yang secara nyata ada yang berpotensi untuk meningkatkan

\footnotetext{
$202-203$

${ }^{15}$ Farida Indrati Suprapto, Ilmu Perundang-undangan, PT. Buku Kita, Jakarta, 2007, hlm. ${ }^{16}$ Ibid., hlm. 206.
} 
kesejahteraan masyarkat sesuai dengan kondisi dan kekhasan dan potensi unggulan daerah yang bersangkutan.

Lebih lanjut dikatakan bahwa kewenangan pembentukan Peraturan Daerah Kabupaten/Kota ini merupakan suatu pemberian wewenang (atribusian) untuk mengatur daerahnya sesuai Pasal 136 Undang-Undang Nomor 32 Tahun 2004 Tentang Pemerintahan Daerah. Pembentukan suatu Peraturan Daerah Kabupaten/Kota dapat juga merupakan pelimpahan wewenang (delegasi) dari suatu peraturan perundang-undangan yang lebih tinggi.

Seorang wakil dianggap duduk di lembaga Perwakilan karena mendapat mandat dari rakyat sehingga disebut mandataris. Teori mandat ini dipelopori oleh Rousseau dan diperkuat oleh Petion dibagi menjadi tiga kelompok pendapat: ${ }^{17}$

1. Mandat Imperatif, menurut teori ini bahwa seorang wakil yang bertindak di lembaga perwakilan harus sesuai dengan perintah (intruksi) yang diberikan oleh yang diwakilinya. Si wakil tidak boleh bertindak di luar perintah, sedangkan kalau ada hal-hal atau masalah baru yang tidak terdapat dalam perintah tersebut maka sang wakil harus mendapat perintah baru dari yang diwakilinya.

2. Mandat Bebas, teori ini berpendapat bahwa sang wakil dapat bertindak tanpa tergantung pada perintah dari yang diwakilinya. Menurut teori ini sang wakil adalah merupakan orang-orang yang terpercaya dan terpilih serta memiliki kesadaran hukum dari masyarakat yang diwakilinya sehingga sang wakil dimungkinkan dapat bertindak atas nama mereka yang diwakilinya. Ajaran ini dipelopori oleh Abbe Sieyes di Perancis dan Block Stone di Inggris. Dalam perkembangan selanjutnya teori ini berkembang menjadi teori Mandat Representatif.

3. Mandat Representative, teori ini mengatakan bahwa sang wakil dianggap bergabung dalam lembaga perwakilan, dimana yang diwakili memilih dan memberikan mandat pada lembaga perwakilan, sehingga sang wakil sebagai individu tidak ada hubungan dengan pemilihnya apalagi untuk minta pertanggungjawabannya.

Materi muatan Peraturan Daerah ditentukan dalam Pasal 12 Undang-

Undang Nomor 10 Tahun 2004 menentukan bahwa materi muatan Peraturan

17 http://legislasi.blogspot.co.id/2008/12/konsep-legislasi.html. Diakses pada tanggal 4 Agustus 2016 pukul 14.35 wib 
Daerah adalah seluruh materi muatan dalam rangka penyelenggaraan otonomi daerah dan tugas pembantuan dan menampung kepentingan khusus daerah serta penjabaran lebih lanjut peraturan perundang-undangan yang lebih tinggi, ditentukan juga bahwa jenis peraturan perundang-undangan selain dimaksud pada Ayat (1) diakui keberadaannya dan mempunyai kekuatan hukum mengikat sepanjang diperintahkan oleh peraturan perundang-undangan yang lebih tinggi. ${ }^{18}$

Peraturan Daerah memiliki hak yuridiksi setelah diundangkan dalam lembaran daerah dan pembentukan Peraturan Daerah berdasarkan asas pembentukan perundang-undangan, yang secara garis besar diatur dalam Pasal 11 Ayat (3) Undang-Undang Nomor 23 Tahun 2014 tentang Pemerintahan Daerah yang meliputi:

a. Kelautan dan perikanan;

b. Pariwisata;

c. Pertanian;

d. Kehutanan;

e. Energi dan sumber daya mineral;

f. Perdagangan;

g. Perindustrian; dan

h. Transmigrasi.

Peraturan Daerah Nomor 25 Tahun 2010 Tentang Retribusi Izin Usaha Perikanan di Kecamatan Tembilahan merupakan Peraturan Daerah yang dibentuk oleh Dewan Perwakilan Rakyat Daerah Kota Tembilahan dengan persetujuan bersama Walikota, yang diundangkan pada tanggal 31 Desember 2010.

${ }^{18}$ Rahimullah. 2007, HukumTata Negara: Ilmu Perundang-Undangan. PT Gramedia, Jakarta, 
Selanjutnya dalam Konsideran Menimbang Peraturan Daerah Nomor 25 Tahun 2010 disebutkan:

1. Bahwa Kabupaten Indragiri Hilir mempunyai wilayah perairan yang cukup luas dengan segala kekayaan didalamnya yang dapat dimanfaatkan guna meningkatkan kesejahteraan masyarakat dengan tetap memperhatikan perlindungamn terhadap kelestarian lingkungan.

2. Bahwa dengan ditetapkannya Undang-Undang Nomor 28 Tahun 2009 tentang pajak daerah dan retribusi daerah perlu melakukan pergantian terhadap Peraturan Daerah kabupaten indargiri hilir Nomor 10 Tahun 2009 tentang Izin Usaha Perikanan;

3. Bahwa berdasarkan pertimbangan sebagaimana dimaksud dalam huruf a dan huruf b perlu membentuk Peraturan Daerah kabupaten Indragiri Hilir Tentang Retribusi Izin Usaha Perikanan

\section{Teori Perizinan}

Hukum adalah Himpunan peraturan-peraturan yang berisi perintahperintah dan larangan-larangan yang megurus tata tertib suatu masyarakat dan kerena itu harus ditaati oleh masyarakat. ${ }^{19}$

Teori Lawrence Meir Friendman dalam Achmad Ali tentang tiga unsur sistem hokum (three Elements of Legal Systim). Ketiga unsur sistem hukum yang mempengaruhi bekerjanya hukum yaitu $:^{20}$

1. Struktur Hukum (Legal Structure)

2. Substansi Hukum (Legal Substance)

\footnotetext{
${ }^{19}$ Sudarsono, Pengantar Ilmu hukum. Cetakan ke 5, PT Rineka Cipta, Jakarta, 2007, hlm. 73

${ }^{20}$ Achmad Ali, Menguak Tabir Hukum (Suatu Kajian Filosofis dan Sosiologis), PT. Tokoh Gunung Agung Tbk, Jakarta, 2001, hlm. 7-9
} 


\section{Kultur Hukum (Legal Calture).}

Menurut Lawrence Meir Friedman dalam Esmi Warassih, ”the structure of system is skeletal framework; it is the permanent shape, the institutional body of the system, the tough, rigid bones that keep the process flowing within bounds" jadi, struktur adalah kerangkanya, bagian yang tetap bertahan, bagian yang memberi semacam bentuk dan batasan terhadap keseluruhan. Jelasnya, struktur bagian foto diam yang menghentikan gerak (a kind of stiil photograph, which freezes the action). ${ }^{21}$

Komponen struktur yaitu kelembagaan yang diciptakan oleh sistem hukum itu dengan berbagai macam fungsi dalam rangka mendukung bekerjanya sistem tersebut. Komponen ini dimungkinkan untuk melihat bagaimana sistem hukum itu memberikan pelayanan terhadap penggarapan bahan - bahan hukum secara teratur.

Selanjutnya, menurut Esmi Warassih, the substance is composed of substantive rulesand rules about how institutions should be have. Yang dimaksud dengan substansi adalah aturan, norma, dan pola perilaku nyata manusia yang berada dalam sistem itu. Substansi juga berarti produk yang dihasilkan oleh orang yang berada di dalam sistem hukum itu, mencakup keputusan yang mereka keluarkan, aturan baru yang mereka susun. Substansi juga mencakup living law (hukum yang hidup), dan bukan hanya aturan yang ada dalam kitab UndangUndang atau Law Books. ${ }^{22}$

${ }^{21}$ Esmi Warassih, Pengantar Sosiologis, PT. Raja GrafindoPersada, Jakarta, 2005, hlm. 14

${ }^{22}$ Ibid., hlm. 15 
Komponen substansi yaitu sebagai output dari sistem hukum yang berupa peraturan-peraturan, keputusan-keputusan yang digunakan baik oleh pihak yang mengatur maupun yang diatur.

Akhirnya, pemahaman Lawrence Meir Friedman dalam Esmi Warassih, tentang the legal culture, system their beliefs, Ideas, and expectation. Kultur hukum adalah sikap manusia terhadap hukum dan sistem hukum kepercayaan, nilai, pemikiran, serta harapannya. "Legal Culture refers. Those parts of general Culture-costoms. Opinions, ways of doing and thinking-that bend social forces to war or away from thelaw and in particular ways". ${ }^{23}$

Pemikiran dan pendapat ini sedikit banyak menjadi penentu jalannya proses hukum. Jadi, dengan kata lain, kultur hukum adalah suasana sosial dan kekuatan social yang menentukan bagaimana digunakan, dihindari atau disalahgunakan. Tanpa kultur hukum, maka sistem hukum itu sendiri tidak berdaya, seperti ikan hidup yang berenang di lautan bebas.

Komponen kultur yaitu terdiri dari nilai-nilai dan sikap-sikap yang mempengaruhi bekerjanya hukum, atau yang disebut sebagai kultur hukum. Kultur hukum inilah yang berfungsi sebagai jabatan yang menghubungkan antara peraturan hukum dengan tingkah laku hukum seluruh warga masyarakat.

Secara singkat, menurut Lawrence Meir Friedman cara lain untuk menggambarkan ketiga unsur sistem hukum itu adalah sebagai berikut $:^{24}$

1. Struktur hukum diibaratkan sebagai mesin

2. Substansi hukum adalah apa yang dikerjakan dan dihasilkan oleh mesin itu.

\footnotetext{
${ }^{23}$ Ibid., hlm. 15

${ }^{24}$ Achmad Ali, Op.Cit., hlm. 17
} 
3. Kultur hukum adalah apa saja atau siapa saja yang memutuskan untuk menghidupkan dan mematikan mesin itu, serta memutuskan bagaimana mesin itu digunakan.

Selain membangun itu, untuk mengenal hukum sebagai sistem maka harus dicermati apakah ia memenuhi 8 (delapan) azas atau principles of legality atau delapan prinsip legalitas.

1. Sistem hukum harus mengandung peraturan-peraturan, artinya ia tidak boleh mengandung sekedar keputusan-keputusan yang bersifat ad hoc.

2. Peraturan-peraturan yang telah dibuat itu harus diumumkan

3. Peraturan tidak boleh berlaku surut

4. Peraturan-peraturan disusun dalam rumusan yang bias dimengerti

5. Suatu sistem tidak boleh mengandung peraturan-peraturan yang bertentangan satu sama lain

6. Peraturan-peraturan tidak boleh mengandung tuntutan yang melebihi apa yang dapat dilakukan

7. Pearturan tidak boleh sering dirubah-rubah

8. Harus ada kecocokan antara peraturan yang diundangkan dengan pelaksanaanya sehari-hari.

Untuk memahami bagaimana fungsi hukum itu, ada kaitannya dipahami terlebih dahulu bidang pekerjaan hukum. Sedikitnya ada 4 (empat) bidang pekerjaan yang dilakukan oleh hukum, yaitu :

1. Merumuskan hubungan-hubungan diantara anggota masyarakat dengan menunjukan perbuatan-perbuatan apa saja yang dilarang dan yang boleh dilakukan. 
2. Mengalokasikan dengan menegaskan siapa saja yang boleh melakukan kekuasaan atau siapa berikut produsernya.

3. Menyelesaikan sengketa yang timbul didalam masyarakat.

4. Mempertahankan kemampuan adaptasi masyarakat dengan cara mengartur kembali hubungan-hubungan dalam masyarakatan manakala ada. Merumuskan hubungan-hubungan diantaraanggota masyarakat menunjukan perbuatanperbuatan apa saja yang dilarang dan yang boleh dilakukan.17

Menurut Satjipto Rahardjo ada 2 (dua) aspek cara kerja hukum dalam hubungan dengan perubahan sosial, yaitu : ${ }^{25}$

1. Hukum sebagai sarana control sosial (Social Control)

Yaitu mempengaruhi warga masyarakat agar tingkah laku sejalan dngan apa yang telah digariskan sebagai urutan hukum, termaksud nilai-nilai yang hidup di dalam masyarakat.

2. Hukum sebagai sarana rekayasa sosial (Social Engineering)

Penggunaan hukum secara sadar untuk mencapai suatu tertib atau keadaan masyarakat sebagaimana diinginkan oleh pembuat hukum.

Berbada dengan fungsi control sosial yang lebih praktis, yaitu untuk kepentingan waktu sekarang, maka fungsi rekayasa sosial dari hukum lebih mengarah pada pembahasan sikap dan perilaku masyarakat dimasa mendatang sesuai dengan keinginan pembuat Undang-undang.

Hukum harus mempunyai 3 (tiga) nilai idealis atau nilai dasar yang merupakan konsekuensi hukum yang baik, yaitu $:^{26}$

${ }_{25}$ Satjipto Rahardjo, Sosiologi Hukum : Perkembangan, Metode dan Pilihan Masalah, Cetakan 1. Muhammadiyah University Press, Surakarta, 1997, hlm. 19-20

${ }^{26}$ Satjipto Rahardjo, Hukum dan Masyarakat, Angkasa, Bandung, 2002, hlm. 21 
1. Keadilan

2. Kemanfaatan/kegunaan

3. Kepastian hukum

Ketertiban masyarakat yang dampak dari luar dalam didukung oleh lebih dari satu macam tatanan. Keadaan yang demikian itu memberikan pengaruhnya tersendiri terhadap masalah efektifitas tatanan dalam masyarakat. Kita melihat efektifitas inin dari segi peraturan hukum, sehingga ukuran-ukuran untuk menilai tingkah laku dan hubungan antara orang-orang pun didasarkan pada hukum dan tatanan hukum. Bahwa masyarakat kita sesungguhnya merupakan suatu rimba tatanan, karena di dalamnya tidak hanya terdapat satu macam tatanan.

Bekerjanya hukum dalam masyarakat Satjipto Rahardjo, dikemukakan dalam dalil-dalil sebagai berikut $:^{27}$

1. Setiap peraturan hukum memberikan tentang bagaimana seorang pemegang peranan (role occupant) itu diharapkan bertindak.

2. Bagaimana seorang pemegang peranan itu akan bertindak sebagai suatu respon terhadap peraturan hukum merupakan fungsi peraturan-peraturan yang ditujukan kepadanya, sanksisanksinya, aktifitas dari lembaga-lembaga pelaksanan serta keseluruhan komplek kekuatan sosial, politik dan lainnya.

3. Bagaimana lembaga-lembaga pelaksana itu akan bertindak sebagai respon terhadap peraturan hukum merupakan fungsi peraturan-peraturan yang ditujukan kepada mereka, sanksi-sanksi, keseluruhan kompleks kekuatanlkekuatan sosial, politik dan lain-lainnya yang mengenai diri mereka serta umpan-umpan balik yang dating dari para pemegang peranan.

\footnotetext{
${ }^{27}$ Satjipto Rahardjo, Ilmu Hukum, PT Citra Aditya,Bandung, 2002, hlm. 21
} 
4. Bagaimana para pembuat Undang-Undang itu akan bertindak merupakan fungsi peraturan-peraturan yang mengantur tingkah laku, sanksi-sanksinya keseluruhan kompleks kekuatan-kekuatan sosial, politik, ideology, dan lainlainnya yang mengenai diri mereka serta umpan-umpan balik yang dating dari pemegang peranan serta birokrasi.

Menurut C.G Howard R.S Sunner dalam R. Soeroso, dikatakan bahwa syarat-syarat yang menentukan kemungkinan hukum menjadi efektif antara lain: ${ }^{28}$

1. Undang-undang yang direncanakan baik dan kaidahnya jelas;

2. Undang-undang sebaiknya bersifat melarang bukan mengharuskan atau membolehkan;

3. Sanksi harus jelas dan sesuai dengan tujuan hukum;

4. Beratnya sanksi tidak boleh berlebihan dengan macam pelanggarannya;

5. Mengandung larangan yang bersesuaian dengan moral.

Negara hukum menurut STAHL unsur unsur negara hukum Rechtsstaat yaitu; ${ }^{29}$

1. Adanya aturan yang nengatur tentang perlindungan HAM

2. Pemisahan kekuasaan

3. Pemerintahan berdasarkan peraturan perundang-undangan

4. Adanya peradilan administrasi negara

Negara hukum menurut STAHL unsur unsur negara hukum Rechtsstaat yaitu; 30

1. Adanya aturan yang mengaatur tentang perlindungan HAM

\footnotetext{
${ }^{28}$ R. Soeroso, Pengantar Ilmu Hukum, Sinar Grafika, Jakarta, 2004, hlm. 221

${ }^{29}$ Ibid., hlm. 221

${ }^{30}$ Ibid., hlm. 222
} 


\section{Pemisahan kekuasaan}

3. Pemerintahan berdasarkan peraturan perundang-undangan

4. Adanya peradilan administrasi negara

Negara hukum rechstaat adalah negara yang menempatkan hukum sebagai dasar kekuasaan negara dan penyelenggaraan kekuasaan tersebut. Negara hukum, segala sesuatu harus dilakukan menurut hukum dan pemerintah harus tunduk terhadap hukum bukan sebaliknya hukum yang tunduk pada pemerintah.

Dalam negara hukum hukum ditempatkan sebagai aturan main dalam penyelenggaraan kenegaraan,pemerintahan,dan kemasyarakatan tujuan hukum itu sendiri antara lain untuk menuju masyarakat yang damai,adil,dan sejahtera. Artinya sasaran dalam suatu negara hukum adalah terciptanya kegiatan kenegaraan, pemerintahan, dan kemasyarakatan yang bertumpu pada keadilan, perdamaian, kemanfaatan dan kesejahteraan

Didalam negara hukum hukum ditempatkan sebagai aturan main dalam penyelenggaraan kenegaraan, pemerintahan, dan kemasyarakatan tujuan hukum itu sendiri antara lain untuk menuju masyarakat yang damai, adil, dan sejahtera. Artinya sasaran dalam suatu negara hukum adalah terciptanya kegiatan kenegaraan, pemerintahan, dan kemasyarakatan yang bertumpu pada keadilan, perdamaian, kemanfaatan, dan kesejahteraan.

Terhadap tugas tugas pemerintahan dan kenegaraan dalam suatu negara hukum terdapat aturan aturan yang tertulis didalam konstitusi/peraturan peraturan yang terhimpun dalam hukum tata negara, untuk penyelenggaraan persoalanpersoalan yang bersifat teknis, hukum tata negara ini tidak sepenuhnya 
dilaksanakan dengan efektif dengan kata lain hukum tata negara membutuhkan hukum yang bersifat teknis yaitu hukum administrasi negara.

Hukum administrasi negara adalah hukum yang mengatur tindkan pemerintah dan mengatur hubungan antara pemerintah dengan warga negara atau hubungan antar organ pemerintahan. Hukum administrasi negara berkaitan erat dengan kekuasaan dan kegiatan penguasa, mengingat bahwa negara merupakan organisasi kekuasaan maka hukum administrasi negara muncul sebagai instrumen untuk mengawasi penggunaan kekuasaan pemerintahan dengan demikian keberadaan hukum administrasi negara muncul karena adanya penyeleneggaraan kekuasaan negara dan pemerintahan dalam suatu negara hukum yang menuntut dan menghendaki penyelenggaraan tugas-tugas kenegaraan, pemerintahan, dan kemasyarakatan berdasarkan atas hukum.

Menurut CJN Versteteden hukum administrasi negara bidang pengaturan anatara laian; ${ }^{31}$

1. Pengaturan mengenai penegakan ketertiban dan keamanan, kesehatan dan kesopanan dengan menggunakan aturan mengenai tingkah laku bagi warga negara yang ditegakkan dan dilanjutkanlebih lanjut oleh pemerintahan.

2. Peraturan yang ditentukan memberikan jaminan sosial bagi rakyat

3. Peraturan peraturan mengenai tata ruang yang ditetapkan pemerintah

4. Peraturan peraturan yang terus berkaitan dengan tugas tugas pemeliharaan dari pemerintah termasuk bantuan dari aktifitas swasta dalam pelayan umum.

5. Peraturan peraturan yang berkaitan dengan pemungutan pajak dan retribusi

\footnotetext{
${ }^{31}$ Satjipto Rahardjo, Op.cit., hlm. 22
} 
6. Peraturan peraturan yang mengenai perlindungan hak dan kepentingan warga negara terhadap pemerintah

7. Peraturan peraturan yang berkaitan dengan penegakan administrasi negara

8. Peraturan peraturan yang mengenai pengawasan organ pemerintahan yang lebih tinggi terhadap organ yang lebih rendah

9. Peraturan peraturan mengenai kedudukan bukum pegawai pemerintahan.

Negara kesatuan dengan sistem administrasi terdapat pula hukum administrasi negara yaitu peraturan yang berkenaan dengan administrasi daerah/pemerintah daerah.

Hukum administrasi negara mencakup hal hal antara lain;32

1. Sarana sarana (instrumen) bagi pengusa untuk mengatur menyeimbangan dan mengendalikan berbagai kepentingan masyarakat

2. Mengatur cara cara partisipasi warga masyarakat dalam proses penyusunan dan pengendalian tersebut, termasuk penentuan kebijaksaan.

3. Perlindungan hukum bagi masyarakat

4. Menyusun dasar-dasar bagi pelaksanaan pemerintahan yang baik

Hukum administrasi negara adalah hukum yang berkenaan dengan pemerintah yang cakupannya secara garis besar mengatur hal hal antara lain; ${ }^{33}$

1. Perbuatan pemerintah (pusat dan daerah) dalam bidang publik

2. Kewenangan pemerintahan (dalam melakukan kewenangan dibidang publik tersebut) didalamnya mengatur mengenai dari mana dengan cara apa, dan bagaimana pemerintah menggunakan kewenangannya, penggunaan

\footnotetext{
32 Ibid., hlm. 21

${ }^{33}$ Achmad Ali, Op.Cit., hlm. 19
} 
kewenangan itu di tuangkan dalam bentuk instrumen hukum sehingga diatur pula tentang pembuatan dan penggunaan instrumen hukum.

3. Akibat hukum yang lahir dari perbuatan atau penggunaan kewenangan pemerintahan itu

4. Penegakan hukum dan penerapan sanksi sanksi dalam bidang pemerintahan

Didalam sumber hukum administrasi negara yaitu menurut sudikno mertokusumo kata sumber hukum dalam beberapa arti yaitu; ${ }^{34}$

1. Sebagai asas hukum, sebagai sesuau yang merupakan permulaan hukum

2. Menunjukkan hukum terdahulu yang memberi bahan bahan pada hukum yang sekarang berlaku seperti hukum pancasila

3. Sebagai sumber berlakunya, yang memberi kekuatan secara formal kepada peraturan hukum (penguasa, masyarakat)

4. Sebagai sumber dari kita mengenal hukum misalnya dokumen-dokumen

5. Sebagai sumber terjadinya hukum, sumber yang terjadinya hukum

Sumber hukum yang hidup didalam hukum admistasi negara adalah sumber hukum formal yaitu di artikan sebagai tempat atau sumber dari mana suatu peraturan memperoleh kekuatan hukum.

Sumber hokum administrasi negara dalam arti formal terdiri dari peraturan perundang-undangan, praktik administrasi negara,yurisprudensi dan doktrin.

1. Peraturan perundang-undangan, peraturan hukum dalam pengertian formal disebut peraturan perundang undngan. Bagir Manan menyebutkan bahwa peraturan perundagan undangan sebagai hukum positif tertulis yang dibuat, ditetapkan atau dibentuk pejabat atau lingkungan jabatan yang berwenang atau

\footnotetext{
${ }^{34}$ Ibid., hlm. 18
} 
berdasarkan ketentuan peraturan perundang-undangan tertentu dalam bentuk tertulis. Berdasarkan Pasal 1 angka 2 Undang-Undang Nomor 5 Tahun 1986 Tentang peradilan tata usaha negara, peraturan perundang-undangan adalah semua peraturan yang bersifat mengikat secara umum yang dikeluarkan oleh badan perwakilan rakyat bersama pemerintah baik ditingkat pusat maupun ditingkat daerah serta semua keputusan badan atau pejabat tata usaha negara baik ditungkat pusat maupun daerah. ${ }^{35}$ Dengan wewenang yang diberikan oleh undang-undang/Peraturan Daerah. Pemerintah daerah dapat membentuk keputusan pemerintah /kepala daerah yang termasuk peraturan perundangundangan yang dapat menjadi dasar bagi pemerinta/pemrtintah daerah untuk mengeluarkan ketetapan.

2. Praktek administrasi negara, menurut L.J Van Apeldorn mengatakan bahwa sekarang ini orang pada umumnya bahwa undang-undang tidak akan oernah lenkap.kehidupan masyarakat sangat rumit dan cepat brubah, sehingga tidak mungkin pembuat undang-undang memuat berbagai persoalan hukum yang mucul dalam masyarakat dengan memuatnya dalam suatu undang-undang pen,tidak ada peraturan yang dapat menikuti pandangan masyarakat ang beragam dan hubungan masyarakat yang berubah-ubah. ${ }^{36}$ Oleh karena itu, administrasi negara dapat mengambil tindakan tindakan yang dua anggap prnting dalam rangka pelayanan masyarakat,meskipun belum ada aturannya dalam undang-undang.Tindakan tindakan yang dilakukan oleh administrasi negara ini akan elahirkan hukum tidak tertulis/konvensi.

\footnotetext{
${ }^{35}$ Undang-Undang Nomor 5 tahun 1986 tentang Peradilan Tata Usaha Negara. Di akses pada tanggal 16 2015. Hari Rabu.pukul 10:00

${ }^{36}$ Achmad Ali, Op.Cit., hlm. 19
} 
3. Yurisprudensi, dalam pengertian teknis yuisprudensi dimaksudkan sebagai putusan badan pengadilan (hakim) yang dikuti secara berulang-ulang dalam kasus yang sama oleh para hakim lainnya sehingga dapat disebut pula hukum ciptaan hakim/peradilan.Yurisprudensi dapat menjadi sumber hukum bagi hukum administrasi negara. A.M Donner menganggap hukum administrasi memuat peraturan peraturan yang $d$ bentuk oleh pembuat undang-undang juga dibentuk oleh hakim. Sehubungan dengan dianutnya asas hakim aktif dan ajaran pembuktian bebas dalam hukum acara peradilan administrasi negara sehingga yurisprudensi akan menempati posisi penting dalam melengkapi dan memperkaya hukum administrasi negara. ${ }^{37}$

4. Doktrin, doktrin adalah ajaran hukum atau pendapat para pakar hukum yang berpengaruh meskipun ajaran hukum atau pendapat para sarjana hukum tidak memilki kekuatan mengikat.

Sudikno Mertokusumo mengatakan bahwa pendapat para sarjana hukum yang merupakan dokrin adalah sumber hukum, tempat hakim menemukan hukumnya. Ilmu hukum adalah sumber hukum tetapi ilmu hukum bukanlah hukum karena tidak mempunyai kekuatan yang mengikat sebagai hukum seperti undang-undang meskipun tidak mempunyai kekuatan yang mengikat sebagai hukum namun tidak berarti bahwa ilmu hukum itu tidak mempunyai wibawa karena mendapatkan dukungan dari para sarjana. Ilmu hukum kecuali mempunyai wibawa juga objektif sifatnya putusan pengadilan harus objektif dan berwibawa juga. ${ }^{38}$ Oleh karena itu, tidak jarang ilmu hukum digunakan oleh hakim dalam

\footnotetext{
${ }^{37}$ Ibid., hlm. 21

38 Sudikno Mertokusumo, Mengenal hukum suatu pengantar, ed.ke-3 cet.ke-1, Liberty, Yogyakarta, 2007, hlm. 71
} 
putusannya sebagai dasar pertimbangan untuk mempertanggung jawabkan putusannya.

Dalam konteks hukum administrasi negara SF.Marbun dan Moh Mahmud mengatakan bahwa doktrin atau pendapat para ahlidapat menjadi sumber hukum formal hukum administrasi negara sebab pendapat para ahli itu dapat melahirkan teori teori dalam lapangan hukum administrasi negara yang kemudian dapat mendorong timbulnya kaidah kaidah hukum administrasi negara. ${ }^{39}$

Perizinan, definisi izin yang sedikit banyak memiliki sejajaran yaitu dispensasi, konsesi dan lisensi. Dispensasi adalah keputusan administrasi negara yang membebaskan suatu perbuatan dari kekuasaan peraturan yang menolak perbuatan tersebut.

Menurut Ateng Syafrudin dispensasi bertujuan untuk menembus rintangan yang sebetulnya secara normal tdidak diizinkan jadi dispensasi berarti menyisihkan pekarangan dalam hal yang khusus. ${ }^{40}$

Lisensi adalah suatu izin yang memberikan hak penyelenggaraan suatu perusahaan. Lisensi digunakan untuk menyatakan suatu izin yang memperkenankan seseorang untuk menjalankan suatu perusahaan dengan izin khusus/istimewa.

Konsesi adalah suatu izin berhubungan dengan pekerjaan besar dimana kepentingan umum terlibat erat sekali sehingga sebenarnya pekerjaan itu menjadi tugas dari pemerintah tetapi oleh pemerintah diberikan hak oleh penyelenggaraanya oleh koesionaris

\footnotetext{
${ }^{39}$ Ridwan HR, 2006, Hukum Administrasi Negara, PT Rajawali Grafindo, Jakarta. Di akses pada tanggal 16-12-2015.hari rabu.pukul 10:00.

${ }^{40}$ Ateng Syafrudin, Perizinan untuk berbagai Kegiatan, Sinar Gafika, Jakarta, 2009, hlm. 81.
} 
Menurut H.D Van Wijk ialah bentuk konsesi terutama digunakan untuk berbagai aktifitas yang menyangkut kepentingan umum yang tidak mampu dijalankan sendiri oleh pemerintah lalu diserahkan kepada perusahaan perusahaan swssta, suatu keputusan administrasi negara yang memperkenankan bersangkutan mengadakan perbuatan tersebut memuat suatu konsesi. ${ }^{41}$

Izin adalah perbuatan hukum administrasi negara bersegi satu yang mengaplikasikan peraturan dalam hal konkret berdasarkan persyaratan dan prosedur sebagai mana yang ditetapkan oleh peraturan perundang-undangan.

Beberapa unsur dalam perizinan yaitu sebagai berikut;

1. Instrumen Yuridis, dalam negara hukum fungsi pemerintah tidak hanya sekedar menjaga ketertiban dan keamanan tetati juga mengupayakan kesejahteraan umum.Izin merupakan instrumen yuridis dalam bentuk ketetapan yang bersifat konstitutif dan yang digunakan oleh pemerintah untuk menghadapi atau menetapkan suatu peristiwa yang konkret.

2. Peraturan perundang-undangan, salah satu prinsip negar hukum adlaah pemerintah berdasarkan peraturan perundang-undangan. Setiap tindakan hukum pemerintah baik dala menjalankan fungsi pengaturan maupun fungsi pelayanan harus didasarkan pada wewenang yang diberikan oleh peraturan perundang-undangan yang berlaku. Pada umumnya wewenang pemerintah untuk mengeluarkan izin itu di tentukan secara tegas didalam peraturan perundang-undangan yang menjadi dasar perizinan tersebut akan tetapi dalam penerapannya kewenangan pemrintah dalam bidang izin itu bersifat diskrosionare power atau berupa kewenangan bebas,dalam arti kepada

${ }^{41}$ Djumialdji, Hukum Bangunan Dasar-Dasar Hukum Dalam Proyek dan Sumber Daya Manusia, Rineka Cipta, Jakarta, 2005, hlm. 65 
pemerintah diberi kewenangan untuk mempertimbangkan atas dasar inisiatif sendiri hal hal yang berkaitan dengan izin, misalnya pertimbangan tentang; kondisi kondisi apa yang memungkinkan suatu izin dapat diberikan kepada pemohon. Bagaimana mempertinbangkan kondisi tersebut, konsekuensi yuridis yang mungkin timbul akibat pemberian atau penolakan izin dikaitkan dengan pembatasan peraturan perundang-undangan yang berlaku. Prosedur apa yang harus diikuti atau di persiapkan pada saat dan sesudah keputusan diberikan baik penerimaan maupun penolakan pemberian izin.

3. Organ Pemerintah, organ pemerintah adalah organ yang menjalankan urusan pemerintahan baik ditingkat pusat maupun ditingkat daerah. Menurut Sjahran Basah bahwa dari penelusuran berbagai ketentuan penyelenggaraan pemerintahan dapat diketahui bahwa milai dari administrasi negara tertinggi sampai terendah berwenang memberikan izin. Ini berarti terdapat aneka ragam administrasi negara (termasuk instansinya) menberi izin yang didasarkan pada jabatan yang dijabatnya baik ditungkat pusat maupun daerah. Keputusan yang memberikan izin harus diambil oleh organ yang berwenang, dan hampir selalu yang terkait adalah organ organ pemerintah atau administrasi negara. ${ }^{42}$

4. Peristiwa Konkret disebutkan bahwa izin merupaka instrumen yuridis yang berbentuk ketetapan, yang digunakan oleh pemerintah dalam menghadapi peristiwa konkret dan individual. Peristiwa konkret artinya peritiwa yang terjadi pada waktu tertentu. Karena peristiwa konkret ini beragam, sejalan dengan keberagaman perkembangan masyarakat, izin memiliki berbagai keragaman. Izin yang sejenisnya beragam itu dibuat dalam proses yang secara

42 Sjachran Basah, Perlindungan Hukum Terhadap Sikap Tindak Administrasi Negara, Alumni, Bandung, 1992, hlm. 42 
prosedurnya tergantung dari kewenangan pemberi izin sepeti izin dan struktur organisasi instansi yang menerbitkannya. Sekedar contoh, dinas Pendapatan Daerah menerbitakan macam jenis izin, salah satunya bagian kesejahteraan rakyat menerbitkan 4 macam jenis izin.

5. Prosedur dan persyaratan, menurut Soehino yaitu syarat syarat izin bersifat konstitutif dan kondisional. Bersifat konstitutif karena di tentukan suatu perbuatan tingkah laku tertentu yang harus terlebih dahulu dipenuhi,artinya dalam hal pemberia izin itu ditentukan suatu perbuatan konkret. Bersifat kondisional, karena penilaian tersebut baru ada dan dapat dilihat serta dapat dinilai setelah perbuatan atau tingkah laku yang disyaratkan itu terjadi. Penetuan prosedur dan persyaratan ini dilakukan secara sepihak oleh pemerintah meskipun demikian, pemerintah tidak boleh membuat atau menentukan prosedur atau persyaratan menurut kehendaknya sendri atau sewenaang wenang, tetapi harus sejalan dengan peraturan perundangundangan yang menjadi dasar perizinan tersebut. Dengan kata lain, pemerintah tidak boleh menetukan syarat yang melampaui batas dan tujuan yang hendak dicapai oleh peraturan hukum yang menjadi dasar perizinan. ${ }^{43}$

Izin merupakan intrumen yuridisyang digunakan oleh pemerintah untuk mempengaruhi para warga mau mengikuti cara yang dianjurkanya guna mencapai suatu tujuan konkrit. Sebagai suatu intrumen izin befungsi sebagai pengarah, perekayasa, dan perancang masyarakat yang adil dan makmur

${ }^{43}$ Soehino, Hukum Tata Negara: Perkembangan Pengaturan dan Pelaksanaan, Pustaka Sinar Harapan, Jakarta, 2006, hlm. 61 
Adapun mengenai tujuan perizinan yang secara umum dapat disebutkan sebagai berikut: ${ }^{44}$

1. Keinginan mengarahkan (mengendalikan sturen) aktifitas aktifitas tertentu (misalnya izin bangunan)

2. Keinginan melindungi objek objek tertentu (izin terbang, izin membongkar pada monumen monumen)

3. Izin hendak membagi benda benda yang sedikit(izin penghuni didaerah padat penduduk

Sesuai dengan sifatnya, yang merupakan bagian dari ketetapan izin selalu dibuat dalam bentuk tertulis secara umum izin memuat sebagai berikut; ${ }^{45}$

1. Organ yang berwenang

2. Yang dialamtkan

3. Diktum

4. Ketentuan ketentuan, pembatasan pembatasan dan syarat syarat

5. Pemberian alasan

6. Pemberitahuan pemberitahuan tambahan.

Didalam perizinan yang ditetapkan oleh pemerintah daerah yaitu Peraturan Daerah Nomor 25 tahun 2010 tentang retribusi izin usaha perikanan yang terdapat dalam bab III yaitu;

\section{Pasal 3}

(1) Setiap orang dan atau badan yang melakukan usaha perikanan dibidang penangkapan, pembudidayaan, pengangkutan, pengolahan, dan pemasaran ikan didaerah wajib memiliki izin.

\footnotetext{
${ }^{44}$ Sjachran Basah, Op.Cit., hlm. 43

${ }^{45}$ Ibid, hlm. 204
} 
(2) Kewajiban memiliki izin sebagaimana yang dimaksud pada Ayat (1),tidak berlaku bagi nelayan kecil.

Pasal 4

(1) SIUP bagi perusahaan perikanan berlaku selama 30 tahun dan dapat diperpanjang untuk jangka waktu yang sama,

(2) Selambat lambatnya dalam jangka waktu 2 tahun sejak SIUP diterbitkan, orang atau badan penerima izin wajib merealisasikan seluruh alokasi yang tercantum dakam SIUP;

(3) SIPI/SIKPI/SPI/SIUPI wajib diperpanjang setiap 1 tahun sekali.

(4) Apabila dalam jangka waktu 2 Tahun orang atau badan penerima izin tidak merealisasikan seluruh alokasi dalam SIUP, maka pemberi izin dapat mencabut izin yang telah diberikan.

Pasal 5

(1)Izin yang dimaksud dalam Pasal 3 Ayat (1) terdiri dari:

a. Surat Izin Usaha Perikanan (SIUP)

b. Surat Izin Penangkapan Ikan (SIPI)

c. Surat Izin Kapal Pengangkut Ikan (SIKPI)

d. Surat Izin Pembudidaya Ikan (SPI)

e. Surat Izin Pengumpulan Ikan (SIUPI)

Ketentuan sanksi adminitrasi dalam Pasal-Pasal tersebut diatas, Pada Pasal 22 Perda Nomor 25 tahun 2010 disebutkan bahwa:

Sanksi Administrasi

Pasal 22 
(1) Dalam hal wajib retribusi tidak membayar tepat pada waktunya atau kurang membayar, dikenakan sanksi adminitrasi berupa bunga 2\% setiap bulan dari retribusi yang trutang dan atau kurang dibayar.

\section{F. Kerangka Konseptual}

Untuk menghindari pemahaman yang menafsirkan yang berbeda-beda tentang judul penelitian ini, maka penulis menyusun kerangka konseptual sebagai perkiraan teoritis sebagai berikut:

1. Penerapan. Arti kata penerapan adalah bisa berarti pemakaian suatu cara atau metode atau suatu teori atau sistem. ${ }^{46}$

2. Perda. Peraturan Daerah adalah Peraturan Perundang-undangan yang dibentuk oleh Dewan Perwakilan Rakyat Daerah dengan persetujuan bersama Kepala Daerah (gubernur atau bupati/wali kota). ${ }^{47}$

3. Izin usaha. Izin usaha adalah izin dari pemerintah yang disyaratkan untuk perbuatan yang pada umumnya memerlukan pengawasan khusus, tetapi yang pada umumnya tidaklah dianggap sebagai hal-hal yang sama sekali tidak dikehendaki. $^{48}$

4. Perikanan. Perikanan adalah kegiatan manusia yang berhubungan dengan pengelolaan dan pemanfaatan sumberdaya hayati perairan. Sumberdaya hayati perairan tidak dibatasi secara tegas dan pada umumnya mencakup ikan, amfibi,

\footnotetext{
46 https://id.answers.yahoo.com/question/index?qid=20111118181316AAUOHb1. Diakses pada tanggal 01 Agustus 2016 pukul 14.35 wib.

$47 \mathrm{https}$ ///www.google.com/?client=firefox-b-ab\#q=Perda+adalah. Diakses pada tanggal 01 Agustus 2016 pukul 14.45 wib.

48 http://repository.usu.ac.id/bitstream/123456789/39388/3/Chapter\%20II.pdf. Diakses pada tanggal 01 Agustus 2016 pukul 15.00 wib.
} 
dan berbagai avertebrata penghuni perairan dan wilayah yang berdekatan, serta lingkungannya. ${ }^{49}$

\section{G. Metode Penelitian}

Metode penelitian penulis gunakan untuk memperoleh pengetahuan yang benar melalui langkah-langkah dengan sistematis. Secraa umum dalam metode penelitian menguraikan hal-hal sebagai berikut :

\section{Jenis Penelitian dan Sifat Penelitian}

Jenis penelitian yang dipakai adalah penelitian hukum sosiologis/empiris. Yang dimaksud dengan penelitian hukum sosiologis/empiris adalah adalah suatu teori yang mempelajari pengaruh hukum terhadap masyarakat dan sebagainya dengan pendekatan dari hukum ke masyarakat. ${ }^{50}$ Dilihat dari sifatnya, penulisan ini bersifat deskriptif yaitu dalam artian memberikan gambaran disertai penjelasan secara sistematik tentang hal-hal yang berkaitan dengan hal yang diteliti. ${ }^{51}$ Penelitian ini dilakukan dengan terjun langsung kelapangan kepada responden dengan cara survey terkait dengan pelaksanaan Peraturan Daerah Nomor 25 Tahun 2010 Tentang Retribusi izin usaha perikanan.di kota Tembilahan (Study ; Pasal 3 Perda Inhil Nomor 25 Tahun 2010 Tentang Retribusi Izin Usaha Perikanan)

\section{Data Dan Sumber Data}

Data yang dikumpulkan dalam penelitian ini adalah berupa data primer yang terdiri dari :

\footnotetext{
${ }^{49}$ https://id.wikipedia.org/wiki/Perikanan. Diakses pada tanggal 01 Agustus 2016 pukul 15.20 wib

${ }^{50}$ Mukti Fajar ND \& Yulianto Achmad, Dualisme Penelitian Hukum Normatif \& Empiris, Pustaka Pelajar, Yogyakarta, 2010, hlm. 34

${ }^{51}$ Ibid., hlm. 141
} 
a. Data primer. Bahan hukum primer merupakan bahan hukum yang bersifat autoritatif berupa peraturan perundang-undangan. ${ }^{52}$ Primer yaitu data yang diperolah secara langsung dari penelitian, yaitu data yang diperoleh langsung dari lapangan penelitian melalui responden.

b. Data sekunder. Bahan hukum sekunder biasanya berupa pendapat hukum/doktrin/teori-teori yang diperoleh dari literatur hukum, hasil penelitian, artikel ilmiah, maupun website yang terkait dengan penelitian. Bahan hukum sekunder pada dasarnya digunakan untuk memberikan penjelasan terhadap bahan hukum primer. ${ }^{53}$ Data sekunder yaitu data yang diambil berdasarkan keterangan-ketarangan atau pengetahuan-pengetahuan yang secara tidak langsung diperoleh melalui study kepustakaan, tulisan-tulisan ilmiah dan sumber-sumber tertulis lainnya.

c. Data tertier. Data hukum tertier merupakan bahan hukum yang memberikan penjelasan dan petunjuk terhadap bahan hukum primer dan bahan hukum sekunder. Biasanya bahan hukum tersier diperoleh dari kamus hukum, kamus bahasa indonesia, kamus bahasa inggris, dan sebagainya. ${ }^{54}$ Data hukum tertier dalam penelitian ini yaitu bahan yang memberikan petunjuk maupun penjelasan terhadap bahan hukum primer dan bahan hukum sekunder dalam bentuk kamus, tulisan tentang laporan-laporan dan jurnal yang berhubungan dengan masalah yang diteliti.

${ }^{52}$ Peter Mahmud Marzuki, Penelitian Hukum, Edisi I Cetakan 5, Kencana, Jakarta, 2006, hlm, 141.

${ }^{53}$ Ibid., hlm. 141.

${ }^{54}$ Ibid., hlm. 142. 


\section{Populasi dan Sampel}

\section{a. Populasi.}

Populasi adalah wilayah generalisasi yang terdiri atas subyek dan obyek dengan kualitas dan karakteristik tertentu yang ditetapkan oleh penelitian untuk dipelajari dan kemudian ditarik kesimpulan. ${ }^{55}$ Jadi dapat dikatakan bahwa populasi adalah jumlah keseluruhan objek yang akan diteliti yang mempunyai karakteristik yang sama, pada tahap ini peneliti mengelompokan populasi dan memilih untuk dijadikan sebagai sampel penelitian, tentunya dengan dasar pertimbangan keterikatan hubungan dengan obyek yang akan diteliti.

b. Sampel.

Sampel adalah bagian dari populasi yang keberadaannya dapat mewakili populasi. ${ }^{56}$ Dalam penelitian ini penulis menggunakan metode purposive sampling dimana peneliti menentukan sampel dari populasi yang telah ditentukan. Untuk lebih jelasnya dapat dilihat pada tabel dibawah ini :

Tabel I.2

Populasi dan Sampel

\begin{tabular}{|c|l|c|c|c|}
\hline No & Responden & $\begin{array}{l}\text { Jumlah } \\
\text { Populasi }\end{array}$ & $\begin{array}{l}\text { Jumlah } \\
\text { Sampel }\end{array}$ & $\begin{array}{l}\text { Persentase } \\
\text { Sampel } \\
\mathbf{( \% )}\end{array}$ \\
\hline 1 & $\begin{array}{l}\text { Pelaku usaha Perikanan di } \\
\text { Tembilahan }\end{array}$ & 12 & 6 & $66,7 \%$ \\
\hline 2 & $\begin{array}{l}\text { Kepala Dinas Kelauatan dan } \\
\text { Perikanan }\end{array}$ & 1 & 1 & $11.1 \%$ \\
\hline 3 & Kepala Dispenda Kab. Inhil & 1 & 1 & $11.1 \%$ \\
\hline & J u m l a h & $\mathbf{1 4}$ & $\mathbf{8}$ & $\mathbf{1 0 0 \%}$ \\
\hline
\end{tabular}

Sumber Data : Data Olahan Tahun 2016.

\footnotetext{
${ }^{55}$ Etta Mamang Sangadji dan Sopiah, Metodologi Penelitian Pendekatan Praktis dalam Penelitian, Andi Offset, Yogyakarta, 2010, hlm. 185.

${ }^{56}$ Musfiqon, Metodologi Penelitian, Prestasi Pustakaraya, Jakarta, 2012, hlm. 90.
} 


\section{Alat Pengumpul Data}

Untuk mempermudah mengumpulkan data dalam penelitian ini, adapun teknik pengumpulan data yang penulis gunakan adalah sebagai berikut :

a. Kuesioner

Kuesioer adalah sejumlah alat pengumpulan informasi dengan cara menyampaikan sejumlah pertanyaan tertulis untuk dijawab secara tertulis pula oleh responden" ${ }^{57}$ Kuesioner penulis berikan kepada 6 orang pelaku usaha budidaya ikan di kecamatan Tembilahan kabupaten Indragiri Hilir.

b. Wawancara

Wawancara adalah teknik pengumpulan data yang dilakuakn dengan cara bertanya langsung kepada responden atau informan. ${ }^{58}$ Penulis melakukan wawancara langsung kepada 1 orang kepala Dinas perikanan dan 1 orang kepala Dispenda Kabupaten Indragiri HIlir.

c. Observasi

Yaitu metode pengamatan yang penulis lakukan secara langsung terhadap responden di lapangan.

\section{Analisis Data}

Setelah data diperoleh dari sumber-sumber analisis data yang dipergunakan dalam penelitian ini menggunakan metode analisis kualitatif, yaitu analisis yang dilakukan dengan memahami dan menyusun data yang telah diperoleh secara sistematis sehingga diperolah gambaran mengenai masalah atau keadaan yang diteliti. Setelah dilakukan analisis data dengan menggunakan metode kualitatif, kemudian akan ditarik suatu kesimpulan

${ }^{57}$ Amirul Hadi dan Haryono, Metode Penelitian, Rineka Cipta, Bandung, 2005, hlm. 137.

${ }^{58}$ Etta Mamang Sangadji dan Sopiah, Op.Cit., hlm. 48. 
dengan menggunakan metode berpikir. Metode berpikir deduktif adalah metode berpikir yang menerapkan hal-hal yang umum terlebih dahulu untuk seterusnya dihubungkan dalam bagian-bagiannya yang khusus. ${ }^{59}$

\footnotetext{
${ }^{59}$ Cholid Narbuko, Metodologi Penelitian, Bumi Aksara, Jakarta, 2003, hlm. 120.
} 


\section{DAFTAR PUSTAKA}

\section{a) Buku-buku}

Ali Achmad. 2001. Menguak tabir Hukum ( Satu Kajian Filosofis dan Sosiologis). PT. Tokoh Gunung Agung Tbk, Jakarta.

Drs.Sudarsono.S.H.M.SI,2007.Pengantar Ilmu hukum.Cetakan ke 5.PT Rineka Cipta, jakarta.

Warassih Esmi, 2005. Pengantar Sosiologis. PT Raja Grafindo Persada, Jakarta.

Warassih Esmi, 2005.Pranata Hukum: Sebuah Telaah sosialogi.PT Suryandaru Utama, Semarang

Kusnardi.S.H Moh dan Prof.Dr.Bintan R.Saragih.MA,1993. Ilmu Negara.Pt.Gaya Media Pratama,Jakarta

Farida Indrati S Maria, 2007. Ilmu Perundang-Undangan 1: Jenis, fungsi dan Materi Muatan. Cetakan Ke-8. Kanisius (Anggota IKAPI), Yogyakarta

Rahimullah. 2007, Hukum Tata Negara: Ilmu Perundang-Undangan. PT Gramedia, Jakarta.

Ridwan HR,2006.Hukum Administrasi Negara.PT RajawaliGrafindo.Jakarta

Soeroso R, 2004. Pengantar Ilmu Hukum. Sinar Grafika, Jakarta.

Rahardjo Satjipto. 1997. Sosiologi Hukum : Perkembangan, Metode dan Pilihan Masalah, Cetakan 1. Muhammadiyah University Press, Surakarta..2002. Ilmu Hukum. PT.CitraAditya

Rahardjo Satjipto,2002,Ilmu Hukum.PT.CitraAditya,Bandung.

Sugiyono,2010,Metode Penelitian,Alfabel,Bandung.

\section{b) Peraturan Perundang-undangan}

Undang-undang No.32 tahun 2004. Tentang Pemerintahan Daerah

Undang-undang No 10 Tahun 2004 Tentang Pembentukan Peraturan perundang undanagan

Undang-undang No 33 Tahun 2004 Tentang Perimbangan Keuangan

Undang-undang Nomor 25 Tahun 2010 Tentang Retribusi Izin Usaha Perikanan

Undang-undang No 5 Tahun 1986 Tentang peradilan tata usaha negara

\section{c) Internet}

pada tanggal 16-12-2015.hari rabu.pukul

10:00https://masguruonline.wordpress.com/2013/09/25/lembaga-pemerintahankabupaten-kota-dan-provinsi

\section{d)Hasil Interview (Wawancara)}

Hasil Wawancara dengan pelaku usaha budidaya ikan air tawar di kecamatan tembilahan pada tanggal 22 september 2015

Hasil Wawancara dengan salah satu anggota Dinas perikanan dan kelautan dikecamatan tembilahan 29 september 2015

Hasil wawancara dengan salah satu anggota satpol pp dikecamatan tembilahan pada tanggal 5 januari 2016 


\section{e) Jurnal}

Ali Azhar, KMS Novyar Satriawan Fikri. 2020. Study Of Law Number 9 Off Regarding Freedom Of Speech In Publice, International Journal of Scientific \& Technology Research 9(1) : 4002-4006

Mulono Apriyanto, KMS. Novyar Satriawan Fikri, Vivi Arfiani Siregar, Jamri, Ali Azhar. 2020. Penyuluhan Tentang Peremajaan Kelapa Sawit Dan Legalitas Lahan Di Kecamatan Kempas Kabupaten Indragiri Hilir, JPM: Jurnal Pengabdian Masyarakat 1(1): 1-16

KMS Novyar Satriawan Fikri , Ali Azhar. 2020. Academic Study Of District Formation South Indragiri. Progressive law review 2 (1) : 1-13

KMS Novyar Satriawan Fikri, Ali Azhar. 2020, Implementation of Discipline Policy for Civil Servants in Indragiri Hilir Regency Post Covid Pandemic 19, Proceedings of the 5th NA International Conference on Industrial Engineering and Operations Management.

Mulono Apriyanto, KMS Novyar Sariawan Fikri, Ali Azhar, 2020. Pendampingan Santri untuk Penurunan Tingkat Pelanggaran Lalu Lintas 1 (2) : 238-247.

KMS Novyar Satriawan Fikri, Herdiansyah, 2019. To Fighting The Covid 19 Virus In Indragiri Hilir. Jurnal Hukum DAS SOLLEN3 (2) : 23-45

KMS Novyar Satriawan Fikri, Fauziah Rahmah. 2018. Pelaksanaan Pemekaran Kecamatan Sentajo Raya Kabupaten Kuantan Singingi Menurut Peraturan Pemerintah Nomor 19 Tahun 2008 Tentang Kecamatan (Studi Terhadap Pasal 4 Huruf C dan D). Jurnal Hukum DAS SOLLEN 1 (4) : 1-10 